\title{
TIESĪBU UZ VALSTS DIENESTU AIZSARDZĪBAS MEHĀNISMI ATTIECĪBĀ UZ SAEIMAS UN PAŠVALDĪBAS DOMES DEPUTĀTU
}

\section{PROTECTION OF RIGHTS TO PUBLIC SERVICE WITH REGARD TO MEMBERS OF PARLIAMENT AND MUNICIPAL COUNCIL}

\author{
Edvīns Danovskis, Dr. iur. \\ Latvijas Universitātes Juridiskās fakultātes \\ Valststiesību zinātṇu katedras docents
}

\section{Summary}

The article analyses the concept of "public service" in the Article 101 of the Constitution of the Republic of Latvia with regard to the members of parliament and municipal councils. The Article outlines the existing mechanisms of protection of rights to public service and criticizes two recent judgments of the Constitutional Court both on methodological and substantial grounds.

Atslēgvārdi: tiesības uz valsts dienestu, deputāts, administratīvs akts, varas dalī̌̌ana

Keywords: rights to public service, member of parliament, member of local council, administrative act, separation of powers

\section{Ievads}

Šajā rakstā skaidrota Satversmes 101. pantā noteikto tiesību pildīt valsts dienestu nozīme attiecībā uz Saeimas deputātu un pašvaldības domes deputātu, kā arī šo tiesību aizsardzības mehānismi. Vienlaikus raksts ir kritika par divu Satversmes tiesas spriedumu metodologiju un pamatotību. Abu spriedumu galarezultāts ir pareizs, taču tajos ietvertās tēzes par Saeimas un pašvaldības deputāta tiesību aizsardzības mehānismu iztrūkumu ir pārsteidzīgas un nepilnīgas. Raksta pirmajā nodaḷā ietverts pārskats par Satversmes 101. pantā ietverto tiesību pildīt valsts dienestu saturu un korelāciju ar Administrativā procesa likumā ietverto administratīvā akta definīciju. Savukārt raksta otrajā un trešajā nodaḷā argumentēts, kādēḷ divos Satversmes tiesas spriedumos izteiktās tēzes par pašvaldības domes deputāta un Saeimas deputāta tiesību aizsardzības lìdzekḷu neesību nav uzskatāmas par judikatūru un tām ir nepieciešami būtiski precizējumi. 


\section{Tiesību uz valsts dienestu subjekts un aizsardzības mehānismi}

Satversmes 101. panta pirmā dal̦a noteic: "Ikvienam Latvijas pilsonim ir tiesības likumā paredzētajā veidā piedalìties valsts un pašvaldību darbībā, kā arī pildīt valsts dienestu." Satversmes 101. pantā paredzētās tiesības pildìt valsts dienestu ir cilvēka pamattiesība, kuras subjekts ir Latvijas pilsonis. Tiesības pildìt valsts dienestu visupirms nozīmē līdzdalỉbas tiesības valsts pārvaldǐšanā. Šādā nozīmē tiesības piedalīties Latvijas valsts pārvaldīšanā ir gan Latvijas pilsoņu pamattiesības, gan no Latvijas valsts esības izrietoša nepieciešamība. Jebkuras valsts institūcijas "atoms" jeb pamatelements ir cilvēks, Latvijas valsts institūciju pamatelements ir Latvijas pilsonis.

Satversmes 101. pants valsts dienestā nodarbinātajām personām paredz konstitucionāli aizsargātu statusu. Tas nozīmē, ka gan tiesību normās noteiktajiem ierobežojumiem, gan individuāliem lēmumiem, kas kavē valsts dienesta pildīšanu (piemēram, ierobežojumiem piekḷuvei valsts dienestam vai atbrīvošanai no valsts dienesta), ir jābūt konstitucionāli attaisnojamiem. Šādā aspektā Satversmes 101. pants ir piemērots arī Satversmes tiesas praksē. Satversmes tiesa vairākkārt ir vērtējusi likumā noteiktu ierobežojumu piekḷuvei valsts dienestam atbilstibu Satversmes 101. pantam. ${ }^{1}$

Jēdziens "valsts dienests" Satversmes 101. panta izpratnē aptver amatus jebkurā valsts institūcijā (likumdošanas, izpildu un tiesu varas institūcijās), ja vien attieciggais amats ir saistìts ar valsts varas funkciju izlietošanu. ${ }^{2}$ Tātad Satversmes 101. panta izpratnē valsts dienesta amats ir, piemēram, Valsts prezidenta, Saeimas deputāta, ministra, tiesneša, ierēdņa, pašvaldības domes deputāta, pašvaldības skolas direktora u. tml. amati neatkarīgi no institūcijas, kurā šìs personas ir nodarbinātas, un nodarbinātības attiecību veida. Savukārt valsts dienesta amati Satversmes 101. panta izpratnē nav amati, kuri nav saistīti ar valsts varas funkciju izpildi, piemēram, valsts institūcijās nodarbināti grāmatveži, skolotāji, ārsti u. c. Jāuzsver, ka administratīvajās tiesībās jēdzienu "valsts dienests" lieto arī šaurākā nozīmē kā vienu no trim nodarbinātības attiecību veidiem valsts pārvaldē, un šādā nozīmē tas attiecas tikai uz ierēdņiem, amatpersonām ar speciālajām dienesta pakāpēm, karavīriem, prokuroriem un nelielu skaitu citās iestādēs nodarbinātajiem. ${ }^{3}$

Satversmes 101. pantā paredzētās tiesības pildìt valsts dienestu aptver tikai konkrētas privātpersonas tiesības būt valsts dienestā, bet ne vairs attiecīgās amatpersonas kompetences apjomu un strīdus, kas tai var rasties ar citām amatpersonām vai institūcijām šà amata izpildes ietvaros. Šo strīdu risināšanas kārtỉba parasti notiek mājas kārtībā, proti, tiesas šādu strīdu risināšanā parasti neiejaucas, jo tas pārkāptu varas dalǐšanas principu. Tiesas šāda veida strīdus

1 Piemēram: Satversmes tiesas 11.04.2006. spriedums lietā Nr. 2005-24-01. Latvijas Vēstnesis, 2006, Nr. 61; Satversmes tiesas 10.05.2007. spriedums lietā Nr. 2006-29-0103. Latvijas Vēstnesis, Nr. 77; Satversmes tiesas 23.12.2019. spriedums lietā Nr. 2019-08-01. Latvijas Vēstnesis, Nr. 258.

2 Danovskis E. Valsts dienesta jēdziens. Grām.: Tiesību interpretācija un tiesību jaunrade - kā atrast pareizo līdzsvaru. Latvijas Universitātes 71. zinātniskās konferences rakstu krājums. Rīga: LU Akadēmiskais apgāds, 2013, 285. lpp. Sk. arī: Kusiņš G. Satversmes 101. panta komentārs. Grām.: Latvijas Republikas Satversmes komentāri. VIII. nodaḷa. Cilvēka pamattiesības. Autoru kolektīvs prof. R. Baloža zinātniskā vadībā. Rīga: Latvijas Vēstnesis, 2011, 391. lpp.

3 Sk.: Briede J., Danovskis E., Koval̦evska A. Administratīvās tiesības. Mācību grāmata. Rīga: Tiesu namu aǵentūra, 2016, 170. lpp. 
skata tikai tad, ja tām šāda kompetence ir piešķirta. Attiecībā uz Satversmes tiesu tā izsmel̦oši noteikta Satversmes tiesas likumā, bet attiecībā uz administratīvo tiesu - pārsvarā (bet ne tikai) - Administratīvā procesa likumā. Administratīvā procesa likuma 1. panta trešajā daḷā ir noteikts, ka administratīvs akts nav iekšèjs lēmums. Tādēḷ strīdi starp amatpersonām un iestādēm principā nav skatāmi administratīvā procesa kārtībā.

Satversmes 101. pantā noteiktās tiesības pildìt valsts dienestu var ierobežot ne tikai ar tiesību normām, bet arī ar individuāliem tiesību aktiem. "Ievērojot Satversmes 101. pantā ietverto tiesību uz piedalǐšanos valsts un pašvaldìbu darbā un tiesību uz valsts dienestu nozīmību, administratīvā akta definīcijā ìpaši uzsvērts, ka "administratīvais akts ir arī lēmums par amatpersonas [..] tiesiskā statusa nodibināšanu, maiṇu, izbeigšanu un šis personas disciplināro sodī̌̌anu, kā arī cits lēmums, ja tas būtiski ierobežo amatpersonas [..] cilvēktiesības". Amatpersonas jēdziens Administratīvā procesa likuma 1. panta izpratnē tādēḷ ir cieši saistìts ar to personu loku, kuras pilda valsts dienestu Satversmes 101. panta izpratnē. [..] par amatpersonām Administrativā procesa likuma izpratnē ir uzskatāmi, piemēram, valsts kontrolieri, tiesībsargs, atvasinātu publisku personu orgānu (piemēram, pašvaldības domes, Latvijas Bankas, Sabiedrisko pakalpojumu regulēšanas komisijas, Finanšu un kapitāla tirgus komisijas) locekḷi." "Tātad principā paši nozīmīgākie lēmumi par valsts dienesta "kodolu" ir administratīvi akti, ja vien attiecīgu lēmumu nevar uzskatìt par politisku lēmumu. ${ }^{5}$ Piemēram, lēmums par Saeimas deputāta ievēlēšanu Saeimas komisijā ir politisks lēmums. Turpretim "ir iespējams, ka administrativo tiesu kontrolei ir pakḷauti citi lēmumi vai rīcība, kas būtiski skar šo personu cilvēktiesības, piemēram, Saeimas Administrācijas lēmums izmaksāt Saeimas deputātam mazāku atlīdzību, nekā viņam paredzēts saskaṇā ar normatīvajiem aktiem". ${ }^{6}$

\section{Pašvaldības domes deputāta statuss un Satversmes tiesas sprieduma kritika}

Kā iepriekš pamatots, pašvaldības domes deputāta amats arī ietilpst Satversmes 101. pantā ietvertajā valsts dienesta jēdzienā, un līdz ar to uz viṇu ir attiecināmas no minētās normas izrietošās konstitucionālās garantijas. Pašvaldỉbas domes deputāts ir amatpersona Administratīvā procesa likuma 1. panta trešās daḷas izpratnē. Šajā normā ir noteikts, ka "administratīvais akts ir arī lēmums par amatpersonas [..] tiesiskā statusa nodibināšanu, maiṇu, izbeigšanu un šīs personas disciplināro sodīšanu, kā arī cits lēmums, ja tas būtiski ierobežo amatpersonas [..] cilvēktiesības”. Tēze, ka atsevišķi pašvaldības domes vai citu institūciju lēmumi attiecībā uz deputātiem ir administratīvi akti, lìdz šim nav apšaubīta. Piemēram, pašvaldỉbu darbību pārraugošā ministra lēmums atstādināt domes priekšsēdētāju no amata ir administratīvs akts un pārsūdzams

4 Briede J., Danovskis E. Politiska lēmuma nozīme administratīvajās tiesībās. Jurista Vārds, 11.08.2015., Nr. 31 (883), 13. lpp.; par amatpersonas jēdzienu Administratīvā procesa likuma 1. panta trešās daḷas izpratnē sk. arī: Briede J., Danovskis E., Kovalıevska A. 2016, 94. lpp.

5 Plašāk sk.: Briede J., Danovskis E. Politiska lēmuma nozīme administratīvajās tiesībās. Jurista Vārds, 11.06.2015., Nr. 31 (883).

6 Briede J., Danovskis E., Koval̦evska A. 2016, 171. lpp. 
administratīvajā tiesā. Likuma "Par pašvaldībām"7 93. panta trešā daḷa noteic, ka "domes priekšsēdētājam 30 dienu laikā pēc vides aizsardzības un reǵionālās attīstības ministra rīkojuma publicēšanas ir tiesības griezties tiesā ar iesniegumu par vides aizsardzības un reǵionālās attīstības ministra rīkojuma atcelšanu. [..]". Lìdz šim administratīvo tiesu praksē nav apšaubìts un licies pašsaprotami, ka šāds lēmums atbilst administratīvā akta pazīmēm un pārbaudāms tieši administratīvajā tiesā. Administratīvais akts ir arī, piemēram, Republikas pilsētas domes un novada domes deputāta statusa likuma ${ }^{8}$ 4. panta pirmajā daḷa paredzētais pašvaldības domes lēmums "anulēt deputāta pilnvaras, ja deputāts vairāk nekā trīs reizes pēc kārtas bez attaisnojoša iemesla nav piedalījies domes sēdē". Šis lēmums izbeidz amatpersonas tiesisko statusu un nav politisks lēmums, tādēl atbilst Administratīiā procesa likumā noteiktajām administratīvā akta pazīmēm. Savukārt ilgu laiku par iekšèjiem lēmumiem un līdz ar to administratīvajām tiesām nepakḷautiem tika uzskatīti lēmumi, kuros pašvaldības deputātam atteikts sniegt viṇa pieprasīto informāciju. ${ }^{9}$ Savukārt zemāk minētā Satversmes tiesas sprieduma iespaidā šie jautājumi atzìti par skatāmiem administratīvā procesa kārtībā. ${ }^{10}$ Arī Republikas pilsētas domes un novada domes deputāta statusa likumā izdarīti grozījumi, kas paredz deputātiem tiesības sūdzēties par informācijas atteikumiem administratīvā procesa kārtībā. ${ }^{11}$ Taču šādu izmaiņu pamatā bija arī cits apsvērums - līdzšinējā prakse Informācijas atklātības likuma piemērošanā privātpersonas nostādīja labākā pozìcijā nekā domes deputātus (identiska iesnieguma izskatīšana un iespēja sūdzēties par neatbildēšanu bija atkarīga no tā, vai pašvaldības domes deputāts informāciju pieprasījis kā deputāts vai kā privātpersona).

Izpratne par pašvaldỉbu domes deputātu statusu bija pietiekami stabila un viennozīmīga; arī šis raksts varētu izpalikt. Tomēr Satversmes tiesas 2018. gada 29. jūnija spriedumā lietā Nr. 2017-32-05 ietvertās tēzes par pašvaldības domes deputāta statusu neatbilst lìdz šim doktrīnā un praksē nostiprinātajai izpratnei par Satversmes 101. panta tvērumu un šo personu tiesību aizsardzības mehānismiem, radot iespaidu, ka līdz šim domes deputātiem nav efektīvu tiesību aizsardzības līdzekḷ. Lietas būtiskie fakti ir šādi. Vides aizsardzības un reg̣ionālās attīstības ministrs pieṇēma lēmumu apturēt Salaspils novada domes lēmumu, ar kuru patstāvīgajās komitejās ievēlēti domes deputāti, uzskatot, ka patstāvīgo komiteju sastāva veidošanā nav ievērots proporcionalitātes princips. Pašvaldības dome iesniedza pieteikumu Satversmes tiesā, prasot ministra lēmumu atcelt. Satversmes tiesa pamatoti atzina, ka pašvaldības domes lēmums par deputātu ievēlēšanu patstāvīgajās komitejās nav normatīvs akts, tādēḷ ministra rīkojums neatbilst likuma "Par pašvaldībām" 49. pantam. Ar to lietas pareizai izskatīšanai būtu pieticis, taču Satversmes tiesas spriedumā ir ietvertas vairākas lietas

\footnotetext{
7 Par pašvaldībām: LV likums. Pieṇemts 19.05.1994. [11.03.2020. red.].

${ }^{8}$ Republikas pilsētas domes un novada domes deputāta statusa likums: LV likums. Pieņemts 17.03.1994. [11.03.2020. red.].

9 Augstākās tiesas Administratīvo lietu departamenta 27.05.2016. lēmums lietā Nr. SKA-1075. Pieejams: http://www.at.gov.lv/downloadlawfile/4300.

10 Augstākās tiesas Administratīvo lietu departamenta 27.11.2018. lēmums lietā Nr. SKA-888. Pieejams: http://www.at.gov.lv/downloadlawfile/5656.

11 Grozijumi Republikas pilsētas domes un novada domes deputāta statusa likumā: LV likums. Pieņemts 13.02.2020.
} 
izskatīšanai nevajadzīgas tēzes un nepamatoti secinājumi par domes deputāta tiesību aizsardzības mehānismiem. Par tiem turpmākajās rindkopās.

Visupirms jānorāda uz būtisku kḷūdu sprieduma juridiskajā metodologijā. Ja pašvaldības dome ir iesniegusi pieteikumu tiesā par ministra rīkojuma atcelšanu, tad Satversmes tiesai visupirms jāpārbauda, vai apturētais lēmums ir normatīvs akts, jo likuma "Par pašvaldībām" 49. pants paredz ministra tiesības apturēt pašvaldības domes izdotos "saistošos noteikumus vai citus normativos aktus”. Ja ministrs ir apturējis tādu pašvaldības lēmumu, kas nav normatīvs akts, tad viņš ir rìkojies ultra vires un līdz ar to šādu ministra lēmumu Satversmes tiesa atceḷ kā likuma "Par pašvaldībām" 49. pantam neatbilstošu. Taču šajā gadījumā Satversmes tiesas sprieduma motìvu daḷā jau pēc tam, kad sākta analìze par likuma "Par pašvaldībām" 49. panta saturu un to, vai domes lēmums par deputātu ievēlēšanu komitejās ir vai nav normatīvs akts, pēkšņi ietverts šāds teikums: "Lai noteiktu, kāda veida akts ir lēmums par pašvaldības domes pastāvīgo komiteju izveidošanu un to sastāva noteikšanu, Satversmes tiesa visupirms noskaidros pašvaldības deputāta tiesisko statusu, domes un tās komiteju izveidošanas kārtību." Pašvaldības domes deputāta tiesiskajam statusam taču nav nekāda sakara ar to, vai lēmums par deputātu ievēlēšanu komitejā ir vai nav normatīvs akts. Arī Satversmes tiesa vēlāk sprieduma 22. punktā visnotal̆ ìsi, bet pareizi norāda, ka domes lēmums par deputātu ievēlēšanu komitejā ir individuāls tiesību akts, taču šì secinājuma izdarīšanai netiek izmantots (un arī nav vajadzīgs) nekas no spriedumā ietvertajām pārdomām par deputātu tiesisko statusu. Tātad pirmā sprieduma kḷūda ir lieku, lietas iznākumam nebūtisku jautājumu analīze, kas turklāt veido diezgan lielu dal̦u no sprieduma teksta. Savukārt lietas iznākumam nebūtisko jautājumu izklāstā ietverti vairāki neprecīzi apsvērumi, kuri vērsti uz to, lai iezīmētu šķietamu problemātiku domes deputāta tiesību aizsardzībā.

Satversmes tiesas sprieduma 19. punktā ir ietverta pareiza, bet lietas iznākumam nevajadzīga tēze par to, ka pašvaldỉbas domes deputātam ir t. s. brīvās pārstāvības mandāts. Spriedumā pareizi skaidrots, ka "pašvaldības domes deputāts pārstāv attiecīgās teritorijas iedzīvotājus kā kopumu, nevis atseviš̌çu iedzīvotāju individuālās intereses". Brīvais pārstāvības mandāts nozīmē, ka vēlētājiem nav tiesību atsaukt atsevišķus deputātus. Tieši tāda ir brīvā pārstāvības mandāta izpratne konstitucionālajās tiesībās. ${ }^{12}$ Taču tālāk spriedumā brīvās pārstāvības mandātam piedēvētas arī tādas sekas, kas no tā neizriet: “Taču atbilstoši brīvā pārstāvības mandāta principam deputāts neatrodas dienesta attiecībās ar pašvaldỉbu un nav ipaši pakḷauts pašvaldībai. Deputāta īpašo tiesisko statusu noteic no deputāta brīvā pārstāvības mandāta principa izrietošās tiesības un pienākumi" (sprieduma 19. punkts). Savukārt sprieduma 25.5. punktā rakstīts šādi: "Deputāts, pildot amata pienākumus, savas tiesības neīsteno arī kā privātpersona, jo deputāta statuss un tam piederīgais tiesību un pienākumu kopums ir publiski tiesisks, tādēḷ pašvaldības domes un tās institūciju pieņemtie individuālie lēmumi, kas skar deputāta subjektīvo publisko tiesību ìstenošanu, nav nedz administratīvie akti, nedz faktiskā rīcība. Tomēr pašvaldības deputāta strīds ar

\footnotetext{
12 Satversmē brīvais pārstāvības mandāts ir nostiprināts Satversmes 14. panta otrajā daḷā. Plašāk par brīvās pārstāvības mandātu sk.: Dišlers K. Latvijas valsts varas orgāni un vinuu funkcijas. Rīga: Tiesu namu aǵentūra, 2004, 83. lpp.; Pleps J., Pastars E., Plakane I. Konstitucionālās tiesības. Papildināts un pārstrādāts izdevums. Rīga: Latvijas Vēstnesis, 2014, 252.-253. lpp.
} 
pašvaldības domi vai tās orgānu ir publiski tiesisks strīds par konkrēta deputāta subjektīvo publisko tiesību izmantošanu un izriet no pašvaldības domes vai tās orgāna rīcības izpildu varas sfērā. Lai arī pašvaldības deputāts pilda publiski tiesisku amatu, deputāta subjektīvo tiesību aizsardzības labad viṇa tiesiskais statuss administratīvajā procesā tiesā ir pielīdzināms privātpersonas statusam.”

No sprieduma nav saprotams, ko nozīmē frāze, ka deputāts neatrodas dienesta attiecībās ar pašvaldību. Ja šì frāze ir lietota Satversmes 101. pantā lietotā jēdziena "valsts dienests" nozīmē, tad viṇa ir nepareiza (sk. šā raksta 1. nodaḷu). Pašvaldības domes deputāts ir pašvaldībā nodarbināta persona. Pašvaldības domes deputāti, Saeimas deputāti, kā arī citas ar politiskiem lēmumiem ievēlētās personas ietilpst t. s. ìpašo amata attiecību grupā - tās ir nodarbinātības attiecības, kuras nav nedz darba tiesiskās attiecības, nedz valsts dienesta attiecības (šaurākā nozīmē). "Īpašo amatu attiecības ir tādas nodarbinātības attiecības, kas rodas tikai no fakta, ka persona ir ievēlēta (iecelta, apstiprināta) amatā ar politisku lēmumu. [..] Šo amatpersonu tiesības un pienākumus individuāls tiesību akts neregulē - viṇām nav ne darba līguma, ne amata apraksta." ${ }^{3}$ Taču arī šajā grupā esošās personas ir nodarbinātas - viṇām ir no likuma izrietoši pienākumi, par kuru izpildi tiek saņemta atlīdzība. Šādā kontekstā pašvaldības domes deputāta kā atvasinātas publiskas personas nodarbinātā statuss neatškịiras no citām šajā nodarbinātības grupā ietilpstošām personām, piemēram, Latvijas Bankas padomes locekḷiem, Valsts kontroles padomes locekḷiem, Saeimas deputātiem u. c. Arī šo personu kā valsts varas institūcijās nodarbinātu personu statusu aizsargā Satversmes 101. pants un viņu statusu ietekmējošie lēmumi, tostarp citi no nodarbinātības attiecībām izrietoši lēmumi (par pabalstiem, kompensācijām utt.) var būt administratīvi akti un līdz ar to pakḷauti administratīvo tiesu kontrolei. Arī iepriekšèjā rindkopā citētajā sprieduma 25.5. punktā ietvertā norāde, ka deputāts, pildot amata pienākumus, savas tiesības neīsteno kā privātpersona, neizslēdz iespēju, ka attiecībā uz deputātu pieṇemts lēmums, kas maina viņa statusu vai būtiski ierobežo viṇa cilvēktiesības, tostarp Satversmes 101. pantā ietvertās cilvēktiesības, ir administratīvs akts. Lìdz ar to šajā Satversmes tiesas spriedumā ietvertais secinājums, ka pašvaldības domes deputāta statusu vai būtiski cilvēktiesības ierobežojoši lēmumi nav administrativi akti, ir nepareizs. Lìdz ar to arī nevajadzīgs un mākslots ir spriedumā ietvertais secinājums, ka "deputāta subjektīvo tiesību aizsardzības labad viṇa tiesiskais statuss administratīvajā procesā tiesā ir pielīdzināms privātpersonas statusam”. Šāda pielīdzināšana nav nepieciešama, viṇa jau ir nostiprināta administratīvā akta definīcijā.

Administratīvā akta definīcijā ir skaidrots, ka administratīvs akts attiecībā uz amatpersonu ir tikai tāds lēmums, kas maina šīs personas statusu vai būtiski ierobežo tās cilvēktiesības. Taču Satversmes tiesas spriedumā ietvertā "pielīdzināšanas" ideja neietver nekādu atrunu par to, kuras no deputāta tiesībām ir un kuras nav aizstāvamas administratīiā procesa likumā, radot iespaidu, ka deputāts var sūdzēties par jebkuru tiesību aizskārumu. Taču šāda pieeja nonāktu pretrunā ar varas dalīšanas principu, saskaṇā ar kuru tiesa nejaucas valsts pārvaldes iekšèjās norisēs. Administratīvajās tiesās jau ir parādījušies dīvaini nolēmumi lietās, kurās deputāti sūdzējušies par to, ka viṇi nav ievēlēti domes

13 Briede J., Danovskis E., Koval̦evska A. 2016, 171. lpp. 
veidotās institūcijās ${ }^{14}$ vai ka viniem netiek nodrošināta iespēja publicēt savu viedokli pašvaldỉbas mājaslapā. ${ }^{15}$ Šà raksta apjoms nel̦auj šeit ietvert kritiku arī par šiem nolēmumiem.

Taču pats pārsteidzošākais jau tā juridiski liekajā un dažviet nepamatotajā sprieduma argumentācijā ir apstāklis, ka Satversmes tiesas "jaunradìtais" deputāta tiesību aizsardzības modelis ir attīstīts lietā, kurā tam nav nekādas nozìmes. Lietas pamatjautājums bija par to, vai pašvaldība ir ievērojusi likuma "Par pašvaldībām" 54. panta pirmajā dạ̦ā noteikto: "Katras politiskās partijas vai vēlētāju apvienības pārstāvju skaitu komitejā nosaka iespēju robežās proporcionāli no katras politiskās partijas vai vēlētāju apvienības ievēlēto deputātu skaitam." Kamēr vien deputāts ir ievēlēts kādā komitejā, viņam nav no likuma izrietošas subjektīvās tiesības prasīt proporcionalitātes ievērošanu. Proti, proporcionalitātes neievērošana nekādi nevar skart atsevišķa deputāta subjektīvās tiesības. Līdz ar to jautājums par šo tiesību aizstāvību administratīvā procesa kārtībā vispār nevar būt aktuāls.

\section{Saeimas deputāta statuss un Satversmes tiesas sprieduma kritika}

Svarīgas atziṇas par Satversmes 101. panta nozīmi attiecībā uz Saeimas deputātiem ir ietvertas Satversmes tiesas 2019. gada 23. decembra spriedumā lietā Nr. 2019-08-01. ${ }^{16}$ Lieta tika ierosināta pēc Saeimas deputāta konstitucionālās sūdzības, kurā cita starpā bija lūgts atzìt par neatbilstošu Satversmes 101. pantam Saeimas kārtības ruḷla normas, kuras paredzēja būtiskus amata pilnvaru ierobežojumus ${ }^{17}$ deputātam, pret kuru uzsākta kriminālvajāšana. Satversmes tiesa šajā lietā pamatoti atzina, ka apstrīdētās Saeimas kārtības ruḷ̦a normas ierobežo Satversmes 101. pantā minētās tiesības pildīt valsts dienestu. Satversmes tiesas spriedumā rakstīts šādi: "Satversmes 101. pants garantē ikvienam Latvijas pilsonim tiesības Saeimas vēlēšanu likumā noteiktajā kārtībā piedalìties Saeimas vēlēšanās un tādējādi rada priekšnoteikumus tam, lai pilsonis varētu piedalīties valsts darbībā. [..] Satversmes 101. pants piešķir tiesības arī būt pieteiktam par deputāta kandidātu un balotēties vēlēšanās. Ja persona ir ievēlēta Saeimā, tad Satversmes 101. pants attiecināms arī uz tiesībām pildìt deputāta amatu. [..] Satversmes 101. pants paredz personai tiesības ne tikai piedalities Saeimas vēlēšanās, bet arī tiesības ievēlēšanas gadījumā pildīt deputāta amatu bez tādas iejaukšanās šà amata funkciju izpildē, kas būtu pretēja vispārējiem tiesību principiem un Satversmē noteiktajām tiesībām" (sprieduma 10. punkts). Tiktāl Satversmes tiesas sprieduma tēzes par Satversmes 101. panta saturu, kā arī secinājums par apstrīdēto normu neatbilstību Satversmei iebildumus nerada.

\footnotetext{
14 Augstākās tiesas Administratīvo lietu departamenta 13.02.2019. lēmums lietā Nr. SKA-1023/2019. Pieejams: http://www.at.gov.lv/downloadlawfile/5744.

15 Augstākās tiesas Administratīvo lietu departamenta 27.11.2018. lēmums lietā Nr. SKA-888/2019. Pieejams: http://www.at.gov.lv/downloadlawfile/5656.

16 Satversmes tiesas 23.12.2019. spriedums lietā Nr. 2019-08-01. Latvijas Vēstnesis, 2019, Nr. 258.

17 Viena no apstrīdētajām normām bija Saeimas kārtības ruḷ̣a 17. panta otrās daḷas pirmais teikums: "Ja Saeima piekrīt kriminālvajāšanas uzsākšanai pret Saeimas locekli, attiecīgais Saeimas loceklis zaudē tiesības piedalīties Saeimas un tās komisiju, kā arī citu to institūciju sēdēs, kurās Saeima viṇu ir ievēlējusi vai apstiprinājusi, līdz kriminālvajāšanas izbeigšanai vai līdz brīdim, kad stājas spēkā notiesājošs tiesas spriedums."
} 
Taču tālākajās sprieduma rindkopās, gluži kā iepriekšējā raksta nodaḷā analizētajā spriedumā, ir ietvertas lietas iznākumam nevajadzīgas un apšaubāmas tēzes. Pēc pareiza secinājuma, ka Saeimā ievēlētai personai "Satversmes 101. pants piešķir tiesības piedalìties Saeimas darbā deputāta statusā”, Satversmes tiesa pēkšņi sāk analizēt Satversmes 101. pantu kopsakarā ar Satversmes 5. pantu, kurš noteic: "Saeima sastāv no simts tautas priekšstāvjiem." Šì norma visupirms noteic Saeimas sastāvu (100 deputāti), un tajā ietvertais jēdziens "tautas priekšstāvji" kopsakarā ar Satversmes 14. panta otro daḷu ("Vēlētāji nevar atsaukt atsevišķus Saeimas locekḷus") tiešām atspoguḷo t. s. deputāta brīvo mandātu - deputāts pārstāv visu tautu, nevis attiecīgo vēlēšanu apgabalu vai kandidātu sarakstu, no kura ievēlēts, tādēl viņš vismaz juridiski nav saistīts nedz ar vēlētāju, nedz politiskās partijas vai citu personu gribu un viṇu nevar atsaukt no amata. Taču Satversmes 5. pants nav "atslēgas norma”, no kuras izrietētu kaut kāds ìpašs Saeimas deputāta statuss - Saeimas deputāta statuss Satversmē nav reducējams tikai uz vienu Satversmes pantu. Turklāt arī šajā Satversmes tiesas spriedumā brīvajam pārstāvības mandātam piešķirta tāda nozīme, kas no tā nekad nav izrietējusi. Proti, no šā principa ir atvasinātas tiesības "piedalìties Saeimas darbā, Saeimas un tās komisiju sēdēs, izsakoties un balsojot tajās, izmantot iesnieguma, iniciatīvas un jautājumu uzdošanas tiesības u. tml., kā arī tiesības pašorganizēties ar citiem deputātiem (piemēram, frakcijās)" (sprieduma 11. punkts). Daḷa no šìm tiesībām izriet no Satversmes (piemēram, par jautājumiem un likumdošanas iniciatīvas tiesībām), daḷa - no Saeimas kārtības ruḷ̂a. Var piekrist, ka spriedumā minētās tiesības ir l̦oti būtiskas deputāta darbā, taču ne tam, ka tās izriet no Satversmes 5. panta un vēl jo vairāk - no brīvā pārstāvības mandāta.

Lietas iznākumam nevajadzīgas un nepilnīgas ir arī sprieduma 12. punktā ietvertās pārdomas par deputāta tiesību aizsardzības mehānismu. Jāatgādina lasītājam, ka šajā lietā deputāts iesniedza konstitucionālo sūdzību par Saeimas kārtības rullī ietvertas normas atbilstību Satversmes 92. un 101. pantam, tātad pieteikumu, kas saskaṇā ar Satversmes tiesas likumu nepārprotami ir Satversmes tiesas kompetencē. Šis nav pirmais gadījums, kad konstitucionālu institūciju amatpersonas ir iesniegušas Satversmes tiesā konstitucionālo sūdzību Satversmes tiesa jau iepriekš ir skatījusi konstitucionālās sūdzības, kuras iesnieguši tiesneši, taču šajās lietās pārdomas par šo personu tiesību aizsardzības iespējām nav ietvertas. ${ }^{18}$ Sprieduma 12. punktā pareizi secināts, ka, "īstenojot Saeimas deputāta amatam piederīgās tiesības un izmantojot amata pilnvaras, Saeimas deputāts pilda publiski tiesiskas funkcijas un nerīkojas privātpersonas statusā. Tomēr vienlaikus Saeimas deputāti bauda arī pamattiesības, kuras atsevišķ̧os gadījumos var pārklāties ar amata pilnvarām”. Taču tālāk spriedumā norādīts: "Likumdevējs jau ir izšksīries par atbilstošas kompetences piešķiršanu Satversmes tiesai, lai tā varētu izskatīt strīdus starp atsevišķiem konstitucionālajiem valsts varas orgāniem vai to daḷām, bet likumos nav noteicis tiesību aizsardzības līdzekli, ar kuru atseviškss Saeimas deputāts - konstitucionāla valsts varas orgāna daḷa - varētu aizsargāt sava amata pilnvaras to aizskāruma gadījumā. Satversmes tiesa atzīst, ka pašlaik ir piel̦aujama atsevišķa konstitucionālā valsts varas orgāna vai tā daḷas tiesību aizsardzības mehānisma nepilnību novēršana

18 Sk., piemēram: Satversmes tiesas 10.05.2013. spriedums lietā Nr. 2012-16-01. Latvijas Vēstnesis, 2013, Nr. 90; Satversmes tiesas 22.06.2010. spriedums lietā Nr. 2009-111-01. Latvijas Vēstnesis, 2010, Nr. 199. 
ar konstitucionālo sūdzību, kura pēc savas būtības un procesuālajiem priekšnoteikumiem ir vistuvākais tiesību aizsardzības līdzeklis, vēl jo vairāk tādēḷ, ka Satversmes 101. pants un 5. pants, kā jau tika norādīts iepriekš, ir savstarpēji cieši saistīti." Galvenais Satversmes tiesas arguments, kas minēts tajā pašā sprieduma punktā, ir šāds: “Tiesiskas valsts princips prasa efektīvu aizskarto tiesību aizsardzības mehānismu. Ar tiesiskas valsts principu nav savienojama situācija, kurā tiesību aizsardzība izpaliktu tādēḷ, ka nav atbilstoša procesuāla tiesību aizsardzības līdzekḷa." Šì tēze turpmāk minēto apsvērumu dēḷ ir pārāk vispārīga un neprecīza.

No Satversmes 92. panta nepārprotami izriet valsts pienākums nodrošināt privātpersonai efektīvus tiesību aizsardzības mehānismus. Arī Satversmes 101. pantā minēto tiesību aizsardzības mehānismi pastāv - tiesību normas, kuras ierobežo Satversmes 101. pantā ietvertās tiesības, aizskartā persona var apstrīdēt Satversmes tiesā, bet individuālus lēmumus, kas skar šo tiesību kodolu vai citādi būtiski ierobežo citas cilvēktiesības, - administratīvajā tiesā. Taču apstāklis, ka konstitucionāla orgāna, citu valsts institūciju vai amatpersonu darbību reglamentē tiesību normas, automātiski nenozīmē, ka jānodrošina šo strīdu risināšanas mehānismi. Daudzas tiesību normas, kas regulē valsts institūciju darbību, regulē šo institūciju iekšejo darbību. Arī Saeimas kārtības rullī ietvertās normas ir vērstas uz parlamenta iekšèjā darba organizāciju, kārtības un paredzamības nodrošināšanu. Nav šaubu, ka šo normu pārkāpumiem dažreiz var būt arī juridiskas sekas, taču šāda veida procesuāli pārkāpumi parasti ir juridiski izvērtējami tikai tiktāl, ciktāl tie skar gala rezultātā pieņemto lēmumu. Piemēram, Saeimas kārtības rullis paredz detalizētus nosacījumus, kādā notiek runas Saeimas sēdē. Saeimas sēdes vadītājs dod gan atḷauju runāt Saeimas sēdē (Saeimas kārtības ruḷ̦a 56. panta pirmā daḷa), gan var pārtraukt runātāju (Saeimas kārtības ruḷ̦a 73. pants). Taču sēdes vadītāja nesaskaņas ar deputātu par Saeimas kārtības ruḷla normu neievērošanu ir Saeimas iekšèjās organizācijas jautājums. Strīdi bieži notiek arī komisijās, piemēram, par to, ka komisijas locekḷu vairākums lemj noteikt darba reglamentu, ierobežojot debašu ilgumu, vai aizliedz deputātam ierakstīt komisijas sēdi ar videokameru. Šāda veida strīdi neskar deputāta statusu un arī būtiski neierobežo cilvēktiesības, tādēl nav risināmi administratīvā procesa kārtỉbā. Vēl jo vairāk - to risināšana pat nebūtu lietderīga arī Satversmes tiesā.

Saeimā, Ministru kabinetā, pašvaldību domēs strīdi par šo institūciju locekḷu tiesībām un procesuālo normu ievērošanu ir ierasti. Saeimā diezgan bieži sēžu laikā rodas domstarpības par vienas vai otras Saeimas kārtības ruḷ,a normas ievērošanu, un parasti šiem strīdiem ir îslaicīgs raksturs. Tie ir raksturīgi politiski izšķirošos brīžos, taču šo strīdu aktualitāte parasti ātri pāriet. Pat pieņemot, ka atsevišķam deputātam Satversmes tiesas likums paredzētu tiesības iesniegt pieteikumu Satversmes tiesā par jebkuru Saeimas vai to struktūrvienību lēmumu, kas skar deputātu un viņam liekas prettiesisks, šo tiesību aizsardzība tiesā parasti būtu neefektīva. Atšķirībā no vairuma sporta sacīkšu, tiesa nevar strīdu izskatīt piecu minūšu laikā pēc tā rašanās. Parasti lieta tiks izskatīta pēc vairākiem mēnešiem, iespējams, pat pēc tam, kad attiecīgās amatpersonas pilnvaru laiks būs beidzies. Savukārt tiesas procesa iznākums parasti būs konstatējums, ka apstrīdētais lēmums vai rīcība bija vai nebija prettiesiska. Taču tālākās sekas šādiem konstatējumiem, visticamāk, nebūs. 
Zināma nenoteiktība jautājumā par deputātu tiesību aizsardzības mehānismiem ir neizbēgama. Administratīvā procesa likuma 1. pantā ietvertā administratīvā akta definīcija attiecībā uz amatpersonām ietver kritēriju "būtiski ierobežo cilvēktiesības". Kā rāda tiesu prakse lietās par citām amatpersonām (piemēram, ierēdṇiem), kritērijs "būtiski" ne vienmēr ir viennozīmīgs un ietver arī tiesas vērtējumu par cilvēktiesību aizskāruma nozīmīgumu. Ir skaidrs, ka likumdošanas procesa ietvaros pieņemtie lēmumi un rīcỉba nekādā ziņā nebūtu uzskatāmi par administratīviem aktiem, jo tie neatbilst citai administratīvā akta pazīmei (publisko tiesību valsts pārvaldes jomā).

Debatei par to, vai esošie Saeimas deputātu tiesību aizsardzības mehānismi ir pietiekami un vai tos vajadzētu pilnveidot, nav viennozìmīga, iepriekš paredzama iznākuma. Lìdz šim administratīvā tiesa pēc būtības nav skatījusi nevienu Saeimas deputāta pieteikumu par iespējamu deputāta tiesību ierobežojumu. Savukārt Satversmes tiesa ne reizi likumdošanas procesā nav konstatējusi tādus Saeimas deputāta tiesību ierobežojumus, kas būtu devuši pamatu konstatēt likuma atcelšanai būtisku procesuālu pārkāpumu. Tas apliecina, ka vismaz šobrīd jautājumam par Saeimas deputātu tiesību aizsardzības līdzekḷiem ir hipotētisks raksturs.

\section{Kopsavilkums}

1. Pašvaldības domes un Saeimas deputāta amats ietilpst Satversmes 101. panta jēdzienā "valsts dienests". Satversmes 101. pants aizsargā valsts dienestā esošas personas tiesības pildìt attiecīgo amatu, taču ne vairs tās tiesiskās attiecības, kas rodas saistībā ar attiecīgajā amatā ietilpstošo funkciju realizēšanu.

2. Ja Saeimas deputāta vai pašvaldības domes deputāta Satversmes 101. pantā paredzētās tiesības aizskar individuāls lēmums, tad šāds lēmums var būt administratīvs akts, ja vien tas maina attiecīgās amatpersonas statusu (un nav politisks lēmums) vai būtiski ierobežo cilvēktiesības. Satversmes tiesas 2018. gada 29. jūnijā spriedumā izteiktais secinājums, ka domes un tās institūciju pieṇemtie individuālie lēmumi, kas skar deputāta subjektīvās publiskās tiesības, nav administratīvi akti, ir kḷūdains.

3. Lēmumi, kas nemaina deputāta statusu vai būtiski neierobežo cilvēktiesības, nav administratīvi akti, tie ir iekšēji lēmumi un saskaņā ar varas dalīšanas principu nav pakḷauti tiesu varas kontrolei. 